\title{
CARTA DA PERSONAGEM DUM POEMA AO SEU AUTOR
}

\author{
José-Alberto Marques*
}

RESUMO: Carta inédita de José-Alberto Marques acerca dos seus Homeóstatos.

Palavras-chave: Homeóstatos. José-Alberto Marques. Poesia Experimental Portuguesa.

O meu nome é Célia e fiz parte dum poema experimental, um homeóstato, isso, era esse o nome. Senti-me mal naquele corpo estranho. Diz-me a consciência que sou um pseudónimo, não passo dum acaso, sei lá se alguma vez existi, o que fui, que fiz, onde nasci. Apenas existo numa página que adoro e não mereço, por ser diferente de todas as páginas que vejo, ao lado, noutros livros da biblioteca. Gostava de me procurar bem, ter notícia de mim, saber onde nasci, com que idade fui parar à folha de papel, qual a cor dos meus olhos, a da pele, que, qual o cabelo, liso, às ondas, enrolado, esguio, isso não poderei saber, mesmo lendo-me por entre as palavras onde me puseram, o local onde me colocaram, quais as palavras vizinhas, o sentido que o autor queria de mim, os dedos que me escreveram. Não sei se tenho a idade do poema, ou tenho outra, se fosse alguém de carne e osso, não sei verdadeiramente, eu não sei verdadeiramente se existi, certamente teria mais anos, que idade, que idade, vamos lá sabê-lo, ainda existirei? E se existir qual será o meu verdadeiro nome.

Certamente nasci na imaginação de quem escreveu esse nome num poema, e penso muitas vezes para comigo, como será aquele que escreveu o meu nome? Se o conhecesse será que o teria amado de perto, de longe, são tudo o que ponho de hipóteses.

\footnotetext{
*Poeta. E-mail: jose.marques.ex58@gmail.com 
Tenho a intuição de que já fui lida, que o meu nome foi soletrado por alguém, penso o que pensarão de mim as pessoas que leram o meu nome, terão gostado dele, pensado em como seria eu quando fui posta no papel do poema por uma esferográfica, lápis, caneta, ou mesmo directamente no computador, manhã alta, madrugada, ao som de música, em silêncio, ao lado dum maço de cigarros, talvez, ou não, ou talvez ou não talvez um whisky, vinho, ou apenas lucidez de abstémio, bem comportado, afinal porque me quis dar vida para que vivesse na memória das pessoas, aquele que escreveu Célia e não Joaquina, Perpétua ou Clara?

Os pensamentos são pedaços de lágrimas que rasgam a carne da face, será que foi isso que me aconteceu, nasci assim ao virar da página dum livro qualquer, no rebuscar dum sonho atrevido para dele nascer como palavra, mas sem alma, sem carne, um defeito de construção, um nome reencontrado num nome esquecido que fez doer, que magoou e feriu? Não. Serei, talvez, alguém que teve vida, andou pela cidade, pelas cidades, pelas aldeias, por países estranhos, longínquos, de capitais enormes, no marulhar de carros, no contínuo movimento debaixo da terra dos metropolitanos, nos bares de baton vermelho, no elevador dos monstros de pedra, mulher, ou mulher-criança que nasceu, cresceu, floresceu, ganhou seios e esperanças, viu-se ao espelho, percebeu o sonho por dentro da íris dos olhos e com eles enfeitiçou aquele que me deu o nome de Célia, quando, na verdade, possivelmente eu tivesse um outro? São interrogações que faço perante este enigma feliz de não conhecer quem "me" escreveu o meu nome num poema, sobretudo um poema estranho, sem rima, sem métrica, com uma mecânica diferente para que o meu nome nunca fosse lido, ou poucas vezes lido, ou por poucos lido, por ciúme, ou incapacidade, quase escondendo-me assim por raiva ou por medo. Ou, talvez, por ser um visionário louco, amante de sonhos, um lírico não lírico.

Então pergunto-me: - onde foi ele buscar o nome Célia?

Tirou-o dum corpo ou duma palavra, duma mistura de palavras, talvez, agora, entendo eu, ele gostava do mundo, de viagens e de leituras em viagens longas. Sim, agora percebo, o seu gosto pelas palavras é subtrair-lhe letras, dar-lhes espaço entre as letras, será?

Texto Digital, Florianópolis, Santa Catarina, Brasil, v. 12, n. 1, p. 200-202, jan./jun. 2016. ISSNe: 1807-9288. 
Foi assim que aconteceu, sem dúvida. Fui eu que disse Céu e ele dizia Lia. E esqueceu uma letra do meu nome. Era mais ao gosto dele. Mas ele, poeta de poemas estranhos porque fez isso?

Os poetas, afinal, enlouquecem com o sentido de ver o mundo por experiências várias das suas escritas.

Só nós infelizes palavras que somos, somos viajantes das suas loucuras.

Quem diria?

Afinal, fui eu, autor que um dia amou a Céulia. Essa palavra azul. 